\title{
Concordance between Actual Level of Punishment and Punishments suggested by Lay People - but with less use of Imprisonment
}

\author{
LEIF PETTER OLAUSSEN *
}

\section{$1 \quad$ Introduction}

Democratic ideals demand that offenders should be punished in accordance with standards shared by citizens. Implicitly, it is assumed that shared perceptions on moral wrongs are converted into positive (penal) law through the law making processes, and that equally shared perceptions of punishments are employed by the courts when they sentence people. In Norway the Supreme Court is the final appeal court for sentences, and it is assumed that its sentences have a decisive influence on the sentencing practices in lower courts. The intention is that the Supreme Court should be a decisive regulator of the actual level of punishment practiced by every court. Now and then, the Supreme Court argues that a sentence that is appealed is not in accordance with people's general sense of justice. When amending a sentence, the Supreme Court states implicitly, and sometimes even explicitly, that the new sentence is in agreement with people's sense of justice without having any kind of empirical evidence to sustain the claim. ${ }^{1}$ As the Supreme Court only has professional judges, it is just possible that the court fixes a level of punishment that is not in accordance with penal attitudes in the population.

To implement a real influence of rank-and-file Norwegians on the courts' processing of criminal cases, and to monitor that the system would comply with ordinary people's sense of justice, lay judges are thought to be important members of our court system. ${ }^{2}$ For

\footnotetext{
Associate professor at Department for Criminology and Sociology of Law, University of Oslo.

For references to a selection of relevant Supreme Court sentences, see Stridbeck, Ytring, Tidsskrift for strafferett (2005) 3 pp. 207-209.

2 Every fourth year a pool of lay judges is established for each court by municipal boards within the court's jurisdiction. From this pool the courts selects randomly an equal number of judges of both sexes to each case.
}

This is an Open-access article distributed under the terms of the Creative Commons Attribution 3.0 Unported License (http://creativecommons.org/licenses/ by/3.0/), permitting all use, distribution, and reproduction in any medium, provided the original work is properly cited. 
more than a hundred years, lower courts have had two lay judges and one professional judge who on equal terms decide both verdict and sentence. Since 1995, the sentence in all cases heard by Norwegian courts of appeal (lagmannsretten) is always decided by four lay judges and three professional judges. In about 46 percent of cases where the verdict is tried by the court of appeal, it is decided by a ten-person jury. ${ }^{3}$ In the rest of such cases the verdict is decided by four lay judges and three professional judges.

Although lay and professional judges formally are on an equal footing when deciding sentences, they are not equals when it comes to knowledge relevant for sentencing. When all judges meet to fix a sentence, lay judges can only evaluate a committed offence against moral standards, the prosecutor's interpretations of law and sentences suggested in court by the prosecutor and defence lawyer. Professional judges can in addition draw on their expert knowledge from their law studies and professional practice. In spite of these differences between lay and professional judges, we know from two studies of lower court sentencing that all three judges agree on sentences in about 95 percent of cases. ${ }^{4}$ In a clear majority of the five percent of cases with a dissenting judgment, one of the lay judges wants a more lenient punishment than his fellow judges, or the professional judge wants a harsher punishment than the two lay judges. These studies do not, however, explain the very high degree of unanimity in sentencing. We don't know if the lay judges are persuaded or put under pressure by the professional judge, or whether the unanimity is an outcome of more or less spontaneous agreement. However, I don't know of any information indicating that lay judges feel that they are 'hostages' in the sentencing process in courts, only doing what the professional judges expect them to do. Only five percent of lay judges answered in a recent survey that they had experienced that a professional judge had tried in an unreasonable way to influence them to change their mind about a sentence. ${ }^{5}$ I think that this indicates that there is a fairly high degree of unanimity in the Norwegian society about what is a fair sentence.

\section{Research question}

Since the late 1980s, Stortinget (the Norwegian parliament) has passed several law amendments that contribute to increasing harshness of punishments for several crimes, although Norway still is a country with a comparatively low level of prisoners. ${ }^{6}$ In addition to serious white collar crimes, different kinds of drug crimes (smuggling, production, buying and selling) a wide spectrum of violent crimes are typical actions which now

\footnotetext{
NOU 2011: 13 p. 150.

Aubert, Straff og lagdeling. (Institutt for samfunnsforskning, Oslo 1963) and Olaussen, Folks tillit til og medvirkning i domstolene, Tidsskrift for strafferett (2005) 2 pp. 119-143.

NOU 2011: 13, p. 280 question 33 and p. 283 question 49. Question 47 at p. 283 shows that 5 percent give an equal answer related to the verdict.

6 See review of amendments 1980-2000 in NOU 2002: 4, kap. 3.4, at pp. 65-75.
} 
are punished harsher than they used to be. So far, the last legislative enactment in line with this trend was in May 2009 when Stortinget decided to increase the punishment for fourteen types of violent actions including rape, sexual intercourse with children and spousal abuse. ${ }^{7}$ All political parties agreed, and several representatives expressed their satisfaction for the unanimity to increase the punishments as they passed the last part of a new penal code for a new century. The minister of Justice said that the amendments generally would increase punishments with about one third, but would double punishments for rape. Members of Stortinget explicitly said that they expected that the courts immediately would start practicing this. However, in November 2009 the Supreme Court found it unconstitutional to do so because the enactment was part of the new penal code, which had not yet come into force. ${ }^{8}$ Since it was expected that it could take a couple of years until the law would come into force, Stortinget in June 2010 passed the same penal law amendments, amending the penal law currently in force. ${ }^{9}$ Now the courts had to increase punishments immediately.

There are no indications in the documents, which were the basis for the processes leading to the law amendments in 2009 and 2010, that members of Stortinget were concerned about what the people they represent in Stortinget thought about the amendments they discussed. Perhaps the politicians did not care about this, or maybe they either believed that their opinion was shared by the population, or that the amendments might be examples of what Bottoms called 'populist punitiveness' among politicians. ${ }^{10} \mathrm{He}$ explicitly mentioned drug crimes, sex related crimes and crimes of violence as types of crimes most prone to this.

However, was this tightening up of punishments in 2009-2010 in accordance with attitudes to punishment among ordinary citizens?

\section{$3 \quad$ Study design}

During autumn 2009, a comprehensive comparative study of citizen's attitudes to punishment was conducted in the five Nordic countries. ${ }^{11}$ The general design of the study

28.05.2009. Besl.O.nr.88 (2008-2009), Amendment of Act 2005-05-20-28 (Straffeloven/Penal code 2005).

Rt. 2009 p. 1412 (Norway).

Act 2010-06-25-46.

Bottoms, The Philosophy and Politics of Punishment and Sentencing, in Clarkson and Morgan (red.). The Politics of Sentencing Reform (Clarendon Press. 1995) pp. 17-49, pp. 39-40.

11 Preliminary results for Denmark, Iceland, Norway and Sweden were presented at the 15. Nordiske kriminalistmøde i København (the 15th Nordic Congress of Criminalists, Copenhagen August 19th 2010), published in Nordic languages in Nordisk Tidsskrift for Kriminalvidenskab (2010) 3 pp. 232-250. 
was a replication of a previous Danish study. ${ }^{12}$ In each country, four internally connected studies were carried out (point $1-5$ below).

1. Citizens' spontaneous and general opinions about level of punishment were explored in a nationwide telephone survey $(\mathrm{N}=1000)$.

2. Citizens' case related penal attitudes were explored in two studies with different designs. One was a post survey; the other was focus groups (see 3 and 4 below). Each of the designs gave unique information about the same phenomena, and the overlapping information from two independent sources represents an important possibility to control the validity of the study. Valid information from both should yield congruent portraits of citizens' attitudes to punishments.

The same research instrument, a questionnaire that included a description of six crimes, was used in both studies. Each case description covered a half to three quarters of a page (between 260 and 514 words), including some information about the perpetrator. ${ }^{13}$ The only heading connected to each case was a number to avoid indication of (a legal) type of crime, and for the same reason all case descriptions were without legal terms. The cases will in the following be referred to by brief case labels indicating what the cases were about. They were presented in the following order in the questionnaire:

- Spousal abuse: a man commits violence against his wife in their home.

- Heroin smuggling: a person addicted to heroin smuggles 250 grams of heroin into Norway.

- Kiosk robbery: a man threatens an employee in a kiosk with a knife to give him the money in the safe, 16.000 NOK.

- Rape: a woman is raped in a hotel by a man whom she meets during a weekend seminar arranged by their employer.

- Bank embezzlement: a female bank employee commits aggravated embezzlement in the bank where she is employed.

- Assault: a man commits assault against another man outside a night open grill bar.

Respondents in the post survey and in the focus groups were asked to answer three questions for each of the six cases:

- Which punishment do you think a court would inflict?

- Which punishment would you yourself inflict?

12 Balvig, Danskernes syn på straf (Advokatsamfundet, København 2006).

13 The information about the perpetrator was systematically varied between questionnaires used in the post survey (a vignette design) to be able to explore if and how different aspect of perpetrator's background would influence punishments suggested by citizens. All together there were 48 variants of the six cases put together in 8 different questionnaires that were mailed to respondents. 
- Which punishment do you think that people in general would inflict?

The respondents could choose their answers among 31 pre-coded alternative sanctions, including no sanction, listed at the back of each case description. ${ }^{14}$ The tick off-list was (implicitly) partly ordered with more lenient sanctions at the top of the list. Respondents were allowed to answer each question by ticking off one or two sanctions.

3. Respondents for the post survey $(\mathrm{N}=3000)$ were selected as a simple random sample, males and females age 18-74, from the national census register. The response rate was 31 percent, which is very low, lower than expected, and may produce biased results. However, the study design has a built-in possibility to reveal biases, because the post survey and the focus groups should give fairly equal results if the participants are unbiased samples of the population. Results based on data from both samples will therefore be reported.

4. Focus group respondents were obtained in Oslo. A market research institute (Opinion AS) recruited 120 participants through telephone interviews, and picked out participants according to specified criteria: equal representation of men and women and of three age groups (18-29 years, 30-49 years, 50-74 years). ${ }^{15}$ People working in the criminal justice sector were not recruited, neither were people educated in law, criminology or psychology. In addition - and most important - the focus group participants' spontaneous and general opinions about level of punishment should be equal to the opinions found in the nationwide telephone survey (see 1 above). In this respect the focus group participants are a matched sample of adult citizens in the country. ${ }^{16}$

The focus group participants were assigned to 12 groups, which had one meeting each in the premises of the market research institute. These meetings were monitored by one of the institute's employees, and each group carried out five activities in sequential order: Participants

- answered the same questionnaire as respondents in the post survey. ${ }^{17}$

- watched a short (14-25 minutes) mock trial film of court proceeding of one of the cases in the questionnaire. ${ }^{18}$

- answered a questionnaire about punishment for the accused in the film. ${ }^{19}$

14 See questionnaire in Olaussen, Hva synes folk om straffenivået? En empirisk undersøkelse. (Novus forlag 2013) p. $217 \mathrm{ff}$.

15117 persons participated because 3 did not come to their group.

16 See Olaussen 2013 tables 3.2 and 3.3 p. 58.

17 Only one variant of each case was used in the questionnaire in focus groups. Se supra note 13.

18 A mock trial film was made of four of the six cases: Heroin smuggling, kiosk robbery, rape, and assault.

19 The same pre coded categories as in the post survey. 
- discussed punishment for the accused in the film for about one hour. They were asked to give their reasons for the punishment they would inflict, and their discussions were taped and later transcribed by the market research institute. They were informed that they were not expected to come to an agreement.

- answered a final questionnaire about punishment for the accused in the film. ${ }^{20}$

When answering the questionnaires, the focus group participants were supervised and not allowed to talk. Having completed a questionnaire, the participant put it in an envelope, closed it, and wrote a unique participant number on the envelope and put it in a box. The unique participant number made it possible to know if participants changed their mind about punishment during the group process. My only relation to the focus group participants was that I could watch and listen to the group activities from a neighbouring room through a one-way screen.

5. The actual level of punishment for the six cases in the questionnaire was set by experienced lower court judges (tingrettsdommere). They read all variants of the six case descriptions used in the survey questionnaire, and were asked to stipulate what the punishment would be if the cases were brought before the court, and they could of course choose any punishment available in penal law. This was done by two independent panels of three judges working in two different cities. Except for the robbery case, the punishments suggested by the panels were very similar and will be denoted as the actual level of punishment. It will be compared with the sanctions that lay citizens participating in the post survey and the focus groups would inflict.

\section{$4 \quad$ Aggregate level analyses: concordance of punishments?}

Although we wanted to know which punishment the respondents themselves would give in each case, respondents in the post survey could of course discuss the cases with family members, friends, or others before they answered the questions. They could phone anyone they considered to be an expert, or consult different sources on the Internet, for instance publicly available court decisions, and they could spend several weeks dwelling on the answers. Focus group participants were in a different situation. They had been phoned by a marketing research institute and asked to participate in a discussion about punishment, which they had accepted, but they did not receive any information about cases or the questionnaire before they arrived at the premises of the marketing research institute for the discussions. There they were asked to answer our questionnaire without talking to anyone else. Within half an hour they should read the questionnaire and figure out completely by their own if they would punish the perpetrators and by which punishment. The total frequencies of different kinds of sanctions suggested for all six cases by 
respondents in the post survey and by the focus group members are presented in table 1 . In this table (and later Figure 1 and 2) data from the post survey only include data from a subgroup ${ }^{21}$ of respondents who answered a questionnaire with case variants ${ }^{22}$ identical to the variants used in the questionnaire for focus group participants.

Table 1: Frequency of sanctions which respondents in the focus groups and in the post survey themselves would impose - total for all six cases. (Weighted data.)

\begin{tabular}{|l|r|r|r|r|}
\hline \multirow{2}{*}{ Sanctions } & \multicolumn{3}{|c|}{ Focus groups } & \multicolumn{2}{|c|}{ Post survey $^{1)}$} \\
\cline { 2 - 5 } No punishment & $\mathbf{N}$ & $\%$ & $\mathbf{N}$ & $\%$ \\
Conflict council mediation & 2 & 0 & 3 & 0 \\
Fine & 30 & 4 & 25 & 4 \\
Conditional imprisonment & 41 & 6 & 21 & 3 \\
Community punishment & 154 & 22 & 156 & 26 \\
Electronic ankle bracelet & 70 & 10 & 53 & 9 \\
Unconditional imprisonment & 22 & 3 & 18 & 3 \\
Treatment & 402 & 58 & 363 & 59 \\
Pay economic compensation & 175 & 25 & 110 & 18 \\
$\quad$ Sum & 307 & 45 & 233 & 38 \\
Percent basis ${ }^{*}$ & 1203 & 173 & 982 & 160 \\
1) Only case variants identical with those included in the questionnaire used in the focus groups are includ- \\
$\quad$ ed. \\
Number of cases in all questionnaires which had a valid answer. (One questionnaire with valid answer to \\
all cases counts as 6.) A few invalid cases/answers are not included. \\
\hline
\end{tabular}

Frequencies in table 1 include all sanctions, whether the respondent ticked off one or two sanctions. Because many ticked off two sanctions the sum of frequencies (1203 and $982)$ is higher than the total sum of cases in all questionnaires with a valid answer (689 and 611), in the focus group and post survey respectively. The tendency to tick off two sanctions was a bit more widespread among focus group participants than among survey participants. That is why the sum of percent frequencies is 173 for the first mentioned and 160 for the last. This difference between the two sets of data is due to two of the sanctions, treatment and payment of economic compensation to the victim, both being ticked off a bit more frequently by focus group participants than by survey participants. These sanctions were virtually always ticked off together with another sanction; mostly (uncon-

${ }_{21}$ The size (N) of the sub groups varied across cases, from 106 to 122.
$22 \quad$ See supra note 13 . 
ditional) imprisonment. The fact that practically every participant in the two population studies suggested a sanction for the six perpetrators, indicates that the participants perceived the perpetrators' actions to be of such a serious character that he should be met with a sanction.

In table 1, there is a remarkable degree of consensus in answers across data sets in type of sanctions chosen by the respondents. Unconditional imprisonment is the punishment with the highest frequency both among respondents in the focus groups (58 percent) and in the post survey (59 percent), or about 60 percent if electronic ankle bracelet is included as a form punishment implying loss of freedom. Payment of economic compensation to the victim, treatment of the offender, and conditional imprisonment follow as the second, third, and fourth most chosen sanctions, with relatively small differences between data sets.

The unanimity in punishments suggested by the respondents compiled in table 1 might, however, hide divergent views on each of the six cases, and this table does not give any information about punishments suggested by citizens compared to level of punishment in courts. As the six professional judges who assessed the cases in the questionnaire agreed that the perpetrator in all cases would be sentenced to unconditional imprisonment, it might be quite informative to know whether the citizens who participated in the study shared the judges' opinion. Figure 1 shows the percent of focus group participants and participants in the post survey who would give the perpetrator unconditional imprisonment. 
Figure 1: Percent of respondents in focus groups and post survey who themselves would impose unconditional imprisonment (incl. electronic ankle bracelets) as punishment. (Weighted data.)

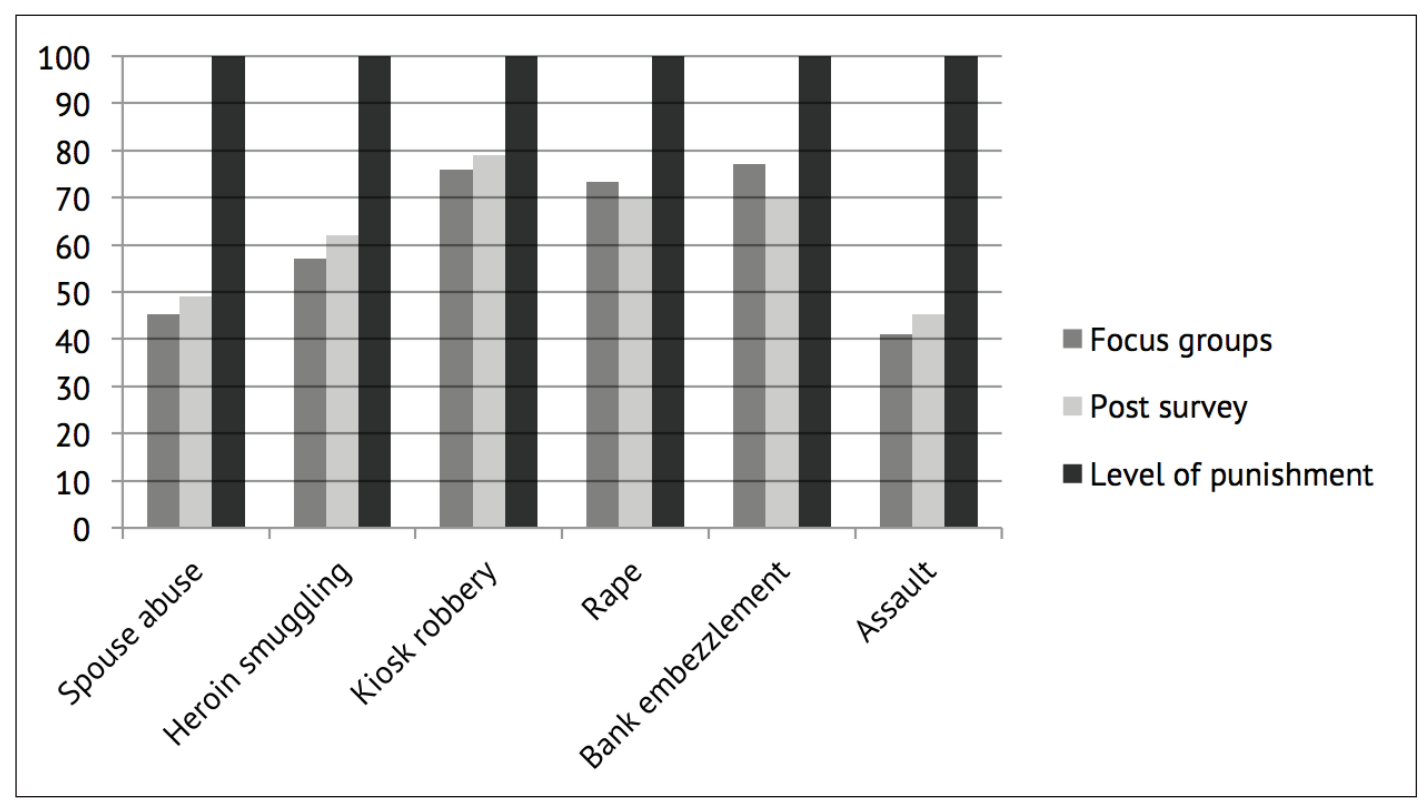

The judges who stipulated the actual level of punishment for the six cases believed that a Norwegian court would give unconditional imprisonment in all cases, indicated with 100 percent in figure 1 . The judges believed that the offender would get 2-5 months in two of the cases, spousal abuse and assault, between 3 and 5 years for heroin smuggling, between 2 and 3 years for kiosk robbery and rape, and five years or more for bank embezzlement. However, figure 1 shows that fairly large parts of respondents in the studies would not themselves give the perpetrator prison punishment. The lower tendency among study participants to suggest unconditional imprisonment is very similar across the studies for all six crimes. The differences in percentage that would give unconditional imprisonment between the population studies are relatively small. For assault and spousal abuse, between 41 and 49 percent would give imprisonment, around 60 percent for heroin smuggling, and between 76 and 79 percent for kiosk robbery, between 70 and 73 percent for rape, and between 70 and 77 percent for bank embezzlement. The percentages in the post survey are, however, a bit higher than among focus group participants in four of the six cases.

The fact that many respondents in both studies would not inflict imprisonment reflects that many Norwegians are reluctant to use this punishment, more reluctant than Norwegian courts are, even in cases considered as relatively serious. Scepticism against prison punishment was express by several focus group participants during their discussions, especially against long prison terms. 
This reluctance to choose imprisonment in specific cases might seem to be contrary to answers from ordinary citizens in the representative, nationwide telephone survey conducted concurrently with the post survey. In the telephone survey 68 percent of interviewed persons agreed that punishments in Norway generally are too lenient, 53 percent agreed that prison conditions are too good, 'like a hotel', 63 percent agreed that prison terms should be longer, and 84 percent agreed that crimes of violence should be punished more harshly. The contrast between such general opinions about punishment expressed in the telephone survey and punishments that lay people would give in specific cases depicted in figure 1 is even more striking when keeping in mind that lay people participating in the focus groups were selected to match the general opinions about punishment expressed in this telephone survey. However, the answers in the telephone survey given to general questions about punishment are of course based on each informant's beliefs about actual level of punishment and prison condition.

But are people well informed about this?

Firstly, as the respondents in the post survey and focus groups were asked to indicate which punishment they believed that a court would inflict for each of the six cases, we know from both studies that Norwegian citizens underestimate the level of punishment: The percentage of focus group participants who answered that a court would inflict unconditional imprisonment was 36 for spousal abuse, 21 for heroin smuggling, 43 for kiosk robbery and for rape, 16 for bank embezzlement, and 36 for assault. ${ }^{23}$ Corresponding percentages for the post survey were very much the same. This surely indicates that laypeople grossly underestimate the courts' use of unconditional imprisonment for serious crimes. These percentages also show that respondents' estimations about the courts' use of imprisonment are even lower than the percent of respondents who would have inflicted this punishment themselves. Secondly, the length of prison terms that respondents believed that a court would inflict was far below the sentences suggested by the professional judges. The modus for the study participants' imagined court sentences, was 6-11 months for heroin smuggling, kiosk robbery, and rape. It was one year less than the actual level of punishment for bank robbery. For spousal abuse and assault, the modus for imagined length of imprisonment given by courts equalled the actual level of punishment, but only a minority of study participants believed that a Norwegian court would inflict unconditional imprisonment in these cases.

Ordinary citizens' lack of knowledge of the actual level of punishment should not be surprising when considering that 30 percent of adult Norwegians don't know that laypeople participate as judges in Norwegian courts. ${ }^{24}$ Many citizens are not familiar with what has been a basic fact about the court system for more than one hundred years, taught in schools in decennia, and frequently mentioned by mass media. Courts are remote insti- 
tutions for most people. As they don't know which sentences the courts practice, many will tend to believe an assertion frequently suggested through mass media: Punishments are too lenient - as the answer to crime problems. People's underestimation of the actual level of punishment is probably echoing cries for harsher punishments forwarded by populist politicians and mass media that rarely publish critical voices.

One might, however, object to my presentation in figure 1 of punishments that study participants would inflict on the perpetrators, that I have only reported data for one of the sanctions that were ticked off. Very many of the respondents among focus group participants would inflict two sanctions: 99 percent for heroin smuggling, 83 percent for assault, 79 percent for spousal abuse, 78 percent for rape, 77 percent for bank embezzlement, and 72 percent for kiosk robbery. (Corresponding percentages for the post survey are very much the same.) When two sanctions were ticked off, one was often imprisonment. Therefore a true reporting of data about sanctions must include all sanctions the participants ticked off, not only imprisonment.

In addition I will also admit that figure 1 overstates the difference between actual level of punishment and laypeople's willingness to use unconditional imprisonment. The reason is that the questionnaires included two sanctions - treatment and economic compensation to the victim, which are not penal sanctions - leading to a deflation of lay people's tendency to tick off imprisonment. I have undertaken a post-test of the questionnaire, which shows that fewer respondents tick off unconditional imprisonment when these extra legal options are available in the questionnaire. ${ }^{25}$ The post-test also indicates that the presence of those options tend to produce a slight decrease in prison terms ticked off.

A true and full reporting of sanctions ticked off by respondents does, however, create a measurement problem: How to 'add together' (measure) two different sanctions chosen by a respondent, for instance one year imprisonment and 100 hours community punishment? A solution presupposes that it is possible to use some kind of common measurement for all sanctions, and a kind of measurement that can be compared with the actual level of punishment. As the sanctions in the questionnaire are of different types, they can only be measured in a sense of order or rank of harshness. This is what is intended with the integers assigned to different sanctions in display 1 . All 31 alternative answers in the questionnaire have been converted to ordinal scale values between 0 (no punishment) and 28 (five or more years imprisonment) on a punishment scale. Since the respondents were allowed to tick off maximum two sanctions per question, the sum of answers to each question will vary between 0 (no punishment) and 44 (unconditional imprisonment 5 years or more + more than 150 hours of community punishment). The integer scale values will later be called PS-values. The scale was established before the data collection was finished.

25 Further details in Olaussen, De nordiske rettsbevissthetsundersøkelsene - noen metodekritiske betraktninger. Nordisk Tidsskrift for kriminalvidenskab (2011) 3 pp. 209-227, and Olaussen 2013 pp. 74-79. 
Display 1: Punishment scale. Conversion of categorical answers in the questionnaire into ordinal penal scale values (PS-values):

\begin{tabular}{|c|c|c|c|}
\hline No punishment & 0 & Electronic ankle bracelets & \\
\hline Conflict council mediation & 1 & Less than 2 months & 10 \\
\hline Fine & & 2 - 3 months & 13 \\
\hline Maximum 1 month's net income & 2 & More than 3 months & 16 \\
\hline 2 - 5 month's net income & 2 & Unconditional imprisonment & \\
\hline 6 month's net income or more & 3 & Less than 2 months & 10 \\
\hline Conditional imprisonment & & $2-5$ months & 13 \\
\hline Less than 2 months & 4 & $6-11$ months & 16 \\
\hline 2 - 5 months & 4 & $1-1$ year and 11 months & 19 \\
\hline $6-11$ months & 4 & 2 years -2 years and 11 months & 22 \\
\hline $1-1$ year and 11 months & 5 & 3 years -4 years and 11 months & 25 \\
\hline 2 years -2 years and 11 months & 5 & 5 years or more & 28 \\
\hline 3 years - 4 years and 11 months & 6 & Treatment of perpetrator & \\
\hline 5 years or more & 6 & Less than 2 months & 2 \\
\hline Community punishment & & Between 2 months and 1 year & 3 \\
\hline Less than 50 hours & 10 & More than 1 year & 5 \\
\hline $50-150$ hours & 13 & Pay economic compensation to victim & \\
\hline \multirow[t]{3}{*}{ More than 150 hours } & 16 & Less than $50.000 \mathrm{NOK}$ & 2 \\
\hline & & $50.000-100.000 \mathrm{NOK}$ & 3 \\
\hline & & More than $100.000 \mathrm{NOK}$ & 5 \\
\hline
\end{tabular}

\section{Conditional imprisonment}

This prison sentence is not served, on the main condition that the sentenced person does not commit a new offence within a period (normally two years) after the sentence. If the sentenced person does not comply with the conditions set by the court, the convict must serve the conditional prison sentence in addition to the punishment for the new crime.

\section{Community punishment}

There is an official 'conversion equation' between this punishment and unconditional imprisonment to be used as a 'rule of thumb' by the court, which determines the sanction: 30 hours of unpaid community work, (which is the 'burden' of this punishment) equal to one month of imprisonment. Values for community sentence of different lengths in the display are tentatively based on this official conversion equation. 


\section{Electronic ankle bracelet}

A law amendment in 2007 made it possible to serve i) a short unconditional prison sentence; or ii) the last few months of a longer unconditional prison sentence; at home, controlled by an electronic ankle bracelet. ${ }^{26}$ This has been the basis for fixing values for electronic ankle bracelets.

\section{Treatment of perpetrator and payment of economic compensation}

It is very difficult to translate the options that could be ticked off for these sanctions into numerical scale values. Comparing both with fines and conditional imprisonment values have been set to the best of my judgement.

The numbers assigned to sanctions only inform about rank, not size. They say for example that imprisonment is more burdensome (harsher) than fines, and 2-3 years imprisonment is harsher than 'less than 2 months' in prison. But the integer 22 assigned to 2-3 years imprisonment does not say that this punishment is about twice as harsh as 'less than 2 months' in prison, since 10 has been assigned to this punishment. I do not intend to measure the amount or degree of harshness of sanctions. That would demand (at least) an interval level of measurement of sanctions, which I don't think is possible. The size of a numeric difference or proportion between two PS-values is not supposed to give any valid information.

Applying PS-values to two sanctions ticked off by respondents and adding the values, will of course increase the PS-value of sanctions for these respondents. The only valid information the increased PS-value gives is that the penal 'burden' (harshness) of both sanctions is higher than any of the two sanctions separately. Because of this, use of the PS-values might also compensate the deflation of respondents' tendency to choose unconditional imprisonment, as mentioned above. The post-test of the questionnaire that I have undertaken indicates that application of PS-values compensates for the deflationary effect, as the median PS-values were equal for respondents who were allowed to choose treatment and economic compensation, and those who were not. ${ }^{27}$

As the PS-values only indicate the relative rank of different sanctions, the only available statistical measure for central tendency that can be used to compare actual level of punishment with questionnaire data of this kind, is the median of PS-values. Balvig used the same procedures as I have..$^{28}$ In a similar way Rossi, Berk, and Campbell compared seriousness scale values of crimes in federal guidelines with medians of ordinal scale values indicating seriousness of crimes in a US survey study. ${ }^{29}$

\footnotetext{
26 Act 2007-06-29-84.

$27 \quad$ See Olaussen 2013 pp. 74-79.

28 Balvig 2006 and his Danskernes retsfølelse og retsfornuft - et forspil (2010) http://www.nyheder.ku.dk/alle_ nyheder/2010/2010.8/danskerne_faengselsstraffe.pdf/.

29 Rossi, Berk and Campbell, Just Punishments: Guideline Sentences and Normative Consensus. Journal of Quantitative Criminology (1997) 13(4) pp. 267-290.
} 
But what information does the median convey? For each of the six crimes, the median of PS-values will split the respondents in two groups of equal size, one with PS-values below the median and other with PS-values above the median. Because the median is exactly in the middle of the distribution of PS-values, it is suitable as a measurement to be compared with actual level of punishment. It tells where the 'point of gravity' in the distribution is, and it reminds us that an equal number of respondents are distributed above and below the median.

Figure 2: Median for PS-values for all sanctions which the respondents themselves would impose on the perpetrator in each case - and actual level of punishment. (Weighted data.)

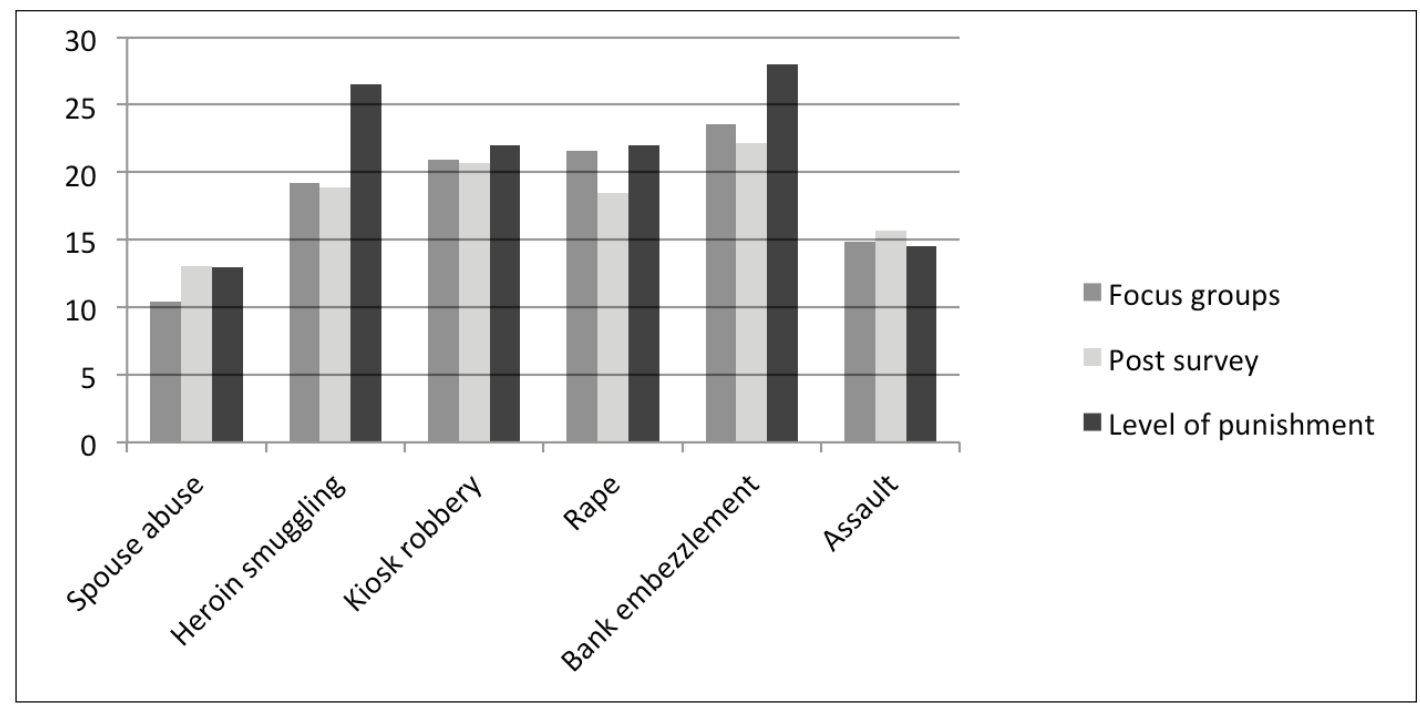

In this figure data from the post survey only include questionnaires with case variants identical with those included in the questionnaire used in the focus groups.

Figure 2 displays the median PS-value for all six cases for both the post survey and the focus groups. The actual level of punishment for the cases suggested by the judges, was also converted to PS-values according to display 1 and is shown in figure 2. Comparing the columns for each crime brings forward two results. Firstly, the medians for the focus group participants and for the post survey are very much equal in size, except for rape and spousal abuse. On average, the respondents inflict the most lenient punishments for spousal abuse, then in ascending order: assault, rape, heroin smuggling, kiosk robbery and the harshest punishments for bank embezzlement. Respondents in both data sets seem to agree very much. Secondly, when comparing median PS-values for all ticked off sanctions (and not only unconditional imprisonment, as in table 1) there also seems to be a fairly good fit between the actual level of punishment and medians for PS-values in the two data sets, except for heroin smuggling and bank embezzlement. According to median PS-values, about fifty percent of Norwegian citizens would inflict sanctions 
with higher PS-values than the PS-value of actual penal level, and about fifty percent of citizens would inflict sanctions with lower PS-values than the PS-value of the actual penal level. In this sense there is a fairly good agreement between sanctions chosen by respondents and the actual penal level. This is not because the participants in my studies are very well informed about the level of punishments practiced by the courts. In section six, I will present and argue for an alternative explanation. But first I will address a couple of questions that might be asked about my use of PS-values in figure 2.

One may object to the comparisons in figure 2 that a Norwegian court most probably would have sentenced the perpetrator to pay the victim an economic compensation in all cases except heroin smuggling and perhaps the kiosk robbery. However, the judges were unfortunately not asked to stipulate economic compensation to the victim. One way to correct for this lack of information about a sanction that judges would have inflicted is to exclude economic compensation from the calculations of total PS-values for the respondents and then recalculate medians for all cases. This has been done, and the median value of the PS-values excluded economic compensation for focus group participants are presented in figure 3, together with the medians for all sanctions and the actual penal level (like in figure 2).

Figure 3: Median of PS-values for all sanctions which focus group members would impose on the perpetrator in each case, for all sanctions except economic compensation, and for actual level of punishment. (Weighted data.)

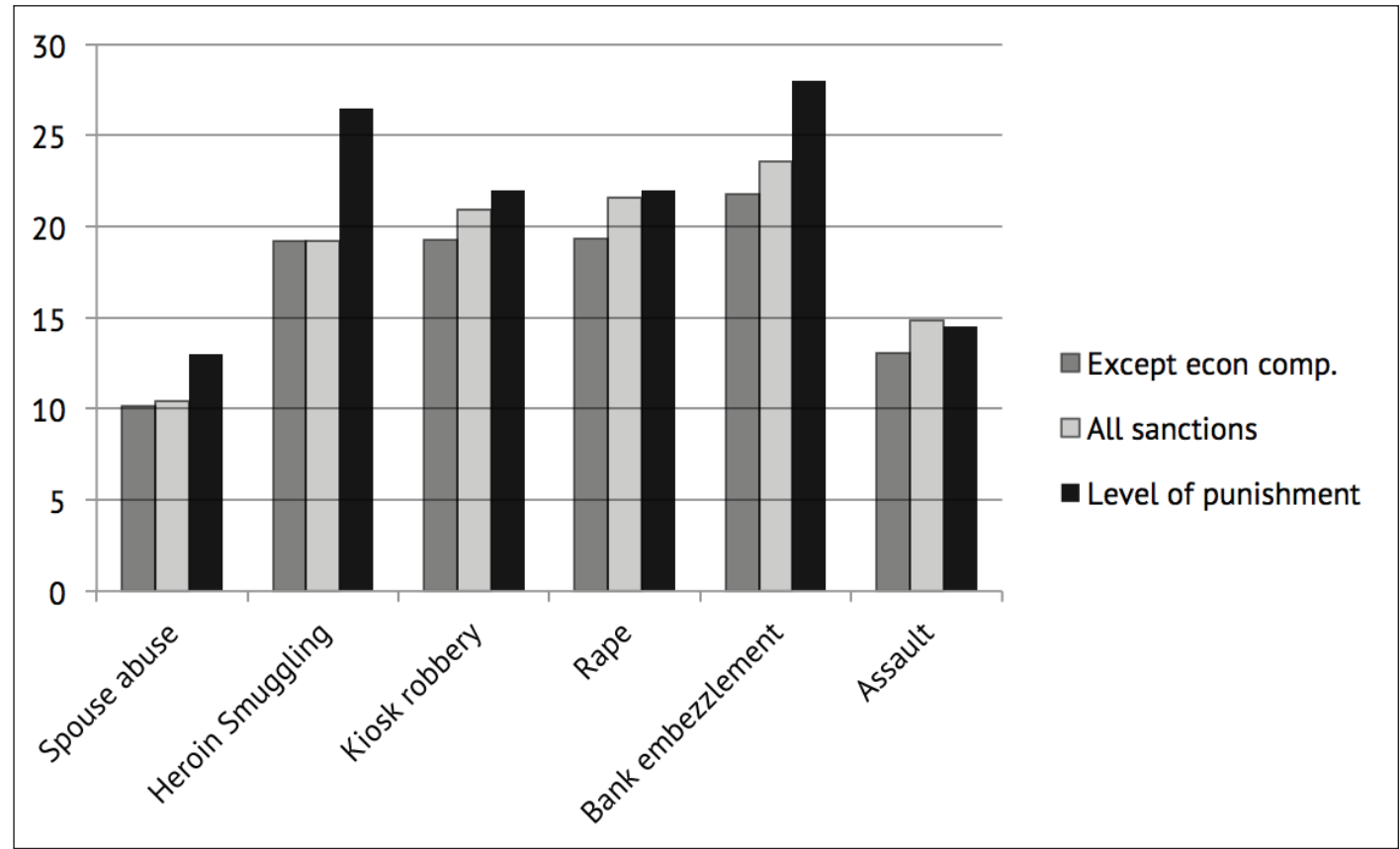


Exclusion of economic compensation from respondent data decreases the median value of PS-values for all crimes except spousal abuse and heroin smuggling, because very few ticked off economic compensation for spousal abuse and only one for heroin smuggling. An additional reason why the median of sanctions decreases after exclusion of economic compensation, is that respondents deflate their tendency to choose unconditional imprisonment when economic compensation is available to them, because they consider this as a punishment that is really felt for a very long time, some of the focus groups participants argued. But although economic compensation was the second most ticked off sanction (see table 1), exclusion of it does not reduce the median values very much. After exclusion there is still a fairly good concordance between medians for respondents and the actual level of punishment.

Figure 3 can also be used to address another question: Would the results be very different if I had chosen different PS-values than the ones in display 1? Results will to some extent depend on numeric values assigned to different sanctions, and this is why I chose to assign other values than the ones used by Balvig in his analysis of comparable Danish data. ${ }^{30}$ I have justified the scale values I chose and discussed the differences between his PS-scale and mine, ${ }^{31}$ and I consider the results in figure 2 to be robust if one sticks to one basic rule: PS-values should reflect that a sanction considered as harsher than another should be assigned a higher value. That was the rule I tried to follow when choosing the numeric values in display 1, and which Balvig did not follow. Figure 3 illustrate that medians of PS-values are fairly robust even for exclusion of sanction, which was very frequently chosen by respondents. Sanctions chosen by very few respondents (fines, electronic ankle bracelet, and conflict council mediation) can only influence the median marginally and should not cause any worry. An important reason for the robustness is the fact that unconditional imprisonment was most frequently ticked off, and the modus of the distribution of unconditional imprisonment ticked off concord with the actual penal level for each of the six crimes.

\section{Individual disagreements about punishment}

Although medians of PS-values for punishments that citizens would inflict on perpetrators show a high degree of concordance across respondent groups, and they comply reasonably well with actual level of punishment, this does not indicate that penal attitudes at an individual level are highly unanimous among respondents. There are considerable disagreements among respondents about which punishment they would inflict on the perpetrator.

To be able to analyse and map the respondents' individual level tendencies to punish, the PS-values (in display 1) for all sanctions each respondent ticked off in the six cases

Balvig 2006 and 2010.

Olaussen 2011. 
were summed to a total PS-value for each respondent in both data sets. There were valid answers for all six cases from 113 respondents in the focus groups and 556 in the post survey. In this section the analysis is based on these subjects. The total PS-value measures each respondent's tendency to inflict (hard) punishments. Theoretically the total penal scale value for the six cases could vary between 0 and 264. Comparison across respondents in both data sets shows that the total PS-value varies greatly across respondents, from minimum 37 to maximum 169 with a median of 106.25 for focus group participants. For the post survey, the minimum was 15, maximum 204 and the median 102.17. This indicates that respondents in both data sets systematically used different parts of the 30 available punishments when they ticked off punishments for the cases. Some used only the more lenient part, while some preferred punishments at the harsher end, and others chose punishments more of a middle range. The distribution of the total scale value for the two data sets in figure 4 shows that both distributions are symmetrical around the median, not too different from the normal curve added as a comparison. The symmetry of the curves confirms that the use of median in figure 2 is a reasonably fair average measurement for the sanctions the respondents would inflict.

Figure 4: Distributions of total PS-value for respondents in post survey $(N=556)$ to the left, and for focus group participants $(N=113)$ to the right.

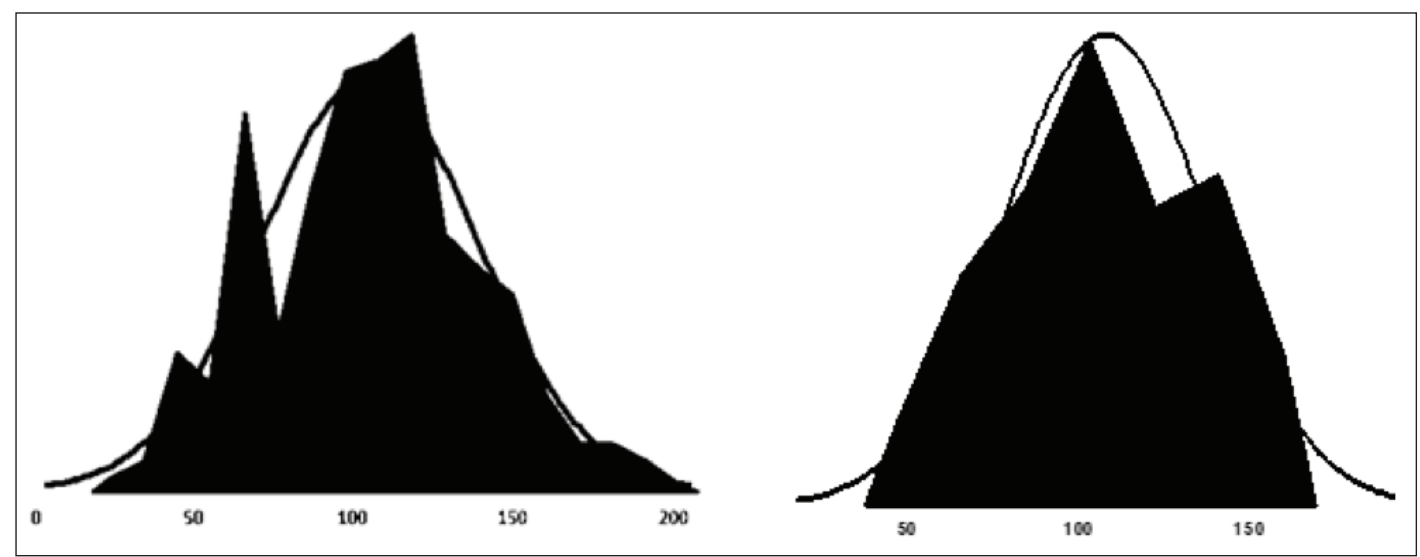

The main difference between the distributions of total PS-values in figure 4 is that the distribution for the post survey is a bit wider than for the focus group participants. A possible reason might be that the focus group participants were recruited to participate in group discussions about punishments. This might have introduced an unforeseen exclusion process either by the recruiters in the market research institute or by those who were invited to participate in discussions, leaving out from the focus groups people who have either extremely lenient or harsh attitudes to punishment. There is, however, no reason to believe that there are any significant differences between respondents from all 
over the country in the post survey and respondents from Oslo in the focus groups, in their tendency to punish the perpetrator in the six cases. Since Black ${ }^{32}$ took it that use of penal sanctions (law) would be positively correlated with degree of urbanisation, post survey data was analysed across six levels of urbanisation for the respondents' living area without finding any systematic differences in tendency to punish. ${ }^{33}$ His theory was not confirmed.

The big individual differences in tendency to punish make it reasonable to ask if there are systematic differences in tendency between subgroups in the data sets. Because respondents were asked very few background questions because we feared that it might influence their choices of punishment, there are few possibilities to check for subgroup differences. Respondents' age and sex are the only ones, and both data sets have been checked to see if these variables are correlated with PS-value. The respondents were divided into four groups according to size of total PS-value for the six cases. The respondent's tendency to inflict harsh punishments might be characterized as weak, fairly weak, fairly strong, and strong according to size of total PS-value for the respondent, relative to the sample distribution of the data set that the respondent belongs to, thus:

Weak tendency

Fairly weak tendency

Fairly strong tendency

Strong tendency
- total PS-value less than or equal to 1. quartile.

- total PS-value between 1. quartile and median.

- total PS-value between median and 3. quartile.

- total PS-value equal to or higher than 3. quartile.

Table 2: Percent distribution of focus group participants according to total PS-value for punishments they would give themselves in six cases. (weighted data)

\begin{tabular}{|c|c|c|c|c|c|c|}
\hline \multirow{2}{*}{$\begin{array}{l}\text { Tendency to } \\
\text { punish (harshly) }\end{array}$} & \multicolumn{2}{|c|}{ Participant's sex } & \multicolumn{3}{|c|}{ Participant's age } & \multirow[b]{2}{*}{ Sum } \\
\hline & Male & Female & $18-29 y s$ & $30-49 y s$ & $50-74 y s$ & \\
\hline Weak & 26.6 & 22.2 & 27,0 & $23, .8$ & 23.7 & 23.0 \\
\hline Fairly weak & 22.9 & 28.3 & 32.0 & 19.2 & 26.2 & 26.5 \\
\hline Fairly strong & 27.5 & 23.7 & 23.8 & 26.2 & 26.2 & 24.3 \\
\hline \multirow[t]{3}{*}{ Strong } & 25.0 & 25.8 & 17.1 & 30.8 & 24.0 & 26.2 \\
\hline & 100.0 & 100.0 & 100.0 & 100.0 & 100.0 & 100.0 \\
\hline & $\mathrm{N}=58.7$ & $\mathrm{~N}=54.7$ & $\mathrm{~N}=24$ & $\mathrm{~N}=47.9$ & $\mathrm{~N}=41.4$ & \multirow[t]{2}{*}{$\mathrm{N}=113.4$} \\
\hline Significance: & \multicolumn{2}{|c|}{$\begin{array}{c}\text { Chi }=1.025 ; \\
\mathrm{P}=0.7952 ; \mathrm{df}=3\end{array}$} & \multicolumn{3}{|c|}{$\mathrm{Chi}=2.531 ; \mathrm{P}=0.8661 ; \mathrm{df}=6$} & \\
\hline
\end{tabular}


Table 2 shows that there are no significant differences between males and females in the focus groups in their tendency to punish, neither are there between age groups. Combining sex and age makes no difference. ${ }^{34}$ The same is true also for post survey data.

Discussions in the focus groups about punishments in four of the cases (rape, kiosk robbery, assault and heroin smuggling) elicit important information about why individual differences in tendency to punish (harshly) are as big as indicated in figure 4 . The focus group moderators' opening question to the participants was something like: Do all of you agree that the offender in the film should be punished? In the questionnaire that participants had answered a few minutes before this question all respondents had ticked off one or two reactions they would inflict on the offender. This indicates that everybody thought that something had to be done. Although the majority of focus group participants nodded or said yes to the moderator's question some reacted by saying something like 'I don't like the word punishment', or 'yes, I would give him a sanction.' Such remarks about denotation signal that group participants had different conceptions of what they did a few minutes earlier as they answered the questionnaire. Many participants had distributed 'punishments'; others had distributed 'sanctions'.

The focus group participants who were reluctant to the moderator's use of the word punishment, were among those who would not give the offender prison punishment or they would only inflict a very short term in prison. Instead they argued for individualised sanctions and tended to give conditional imprisonment or community punishment, frequently in combination with treatment of the offender or economic compensation to the victim. They argued that the sanction should fit the problem that the offender seemed to have, and which possibly was the reason for his criminal action. They tended to search for a remedy or cure that 'modern rational minds' (Max Weber) find more effective and efficient than imprisonment, which they argued would be detrimental for the offender's future life. In other words, their sanctioning philosophy was problem-oriented. These focus group participants would try to solve the offender's assumed problem. As a consequence, that would lead to less crime in coming years. However, other participants who let the moderator's denotation pass, would more readily give the offender prison punishment, quite often combined with treatment or economic compensation or something else. For them, possible effects of the sanction on future crime or on the perpetrator's future seemed to be of lesser interest. The penal system is there to be used whether it has this or that unintended effect. Their approach was primarily preoccupied with the wrong action, its moral character, and its consequences for the victim and society. They seemed to be committed to punish the perpetrator for his action, and their sanctioning philosophy might be called retribution-oriented. The problem- and retribution-orient- 
ed orientations are parallel to treatment and punitive norms, which Aubert claimed would create strain when they are combined in criminal justice systems. ${ }^{35}$

A probable reason why such conflicting normative orientations prevailed among focus group participants when they argued for sanctions against crimes is that the orientations reflect a general dilemma in human thinking about punishment, exemplified in Plato's dialogue Protagoras more than 2300 years ago. Protagoras, who asks Socrates to consider what it means to punish somebody, argued that 'rational punishment' is inflicted to teach virtue and prevent wrongs in the future. ${ }^{36}$ One must 'have regard to the future' (look ahead), Protagoras says, and not retaliate for a past wrong which cannot be undone. Protagoras claims that

\footnotetext{
[t]his is the notion of all who retaliate upon others either privately or publicly. And the Athenians, too, your own citizens, like other men, punish and take vengeance on all whom they regard as evil doers; and hence, we may infer them to be of the number of those who think that virtue may be acquired and taught
}

The retaliation or vengeance he accepts as rational, obviously is a response for a wrong, a past action, so Protagoras advises to look back to what was done. But only doing that would be to punish 'under the notion, or for the reason, that he has done wrong - only the unreasonable fury of a beast acts in that manner', Protagoras says. His double perspective, that a rational punishment inflicted on the evildoer reprobates the wrong action, but with regard for future effects of the punishment, is easily recognised both in focus group participants' arguments, and in Andenæs' theory of punishment that he denoted a 'modified utility theory.' ${ }^{37}$

My understanding of the focus group participants' stated reasons for sanctions they would give the perpetrator in the case they discussed, is that their approach to sanctioning might be described as an individually varying mixture of two orientations, a retribution-oriented and a problem-oriented approach. Most participants promoted or accepted arguments reflecting both orientations. However, some participants were mainly 'looking back' to the committed action and its consequences while others mainly were 'looking ahead', considering future effects of the sanctions. And this is what is reflected in the form of the distributions in figure 4 . Those who were very reluctant to or against use of imprisonment, because it would not solve the perpetrator's problems, but rather be detrimental for him and for society, have the lowest total PS-values. The highest total PS-values are found among those who are most oriented towards retribution, and would

35 Aubert, Legal justice and mental health, Psychiatry: Journal for the Study of Interpersonal Processes (1958) pp. 101-113.

36 This and the following quotes are from: Plato: Protagoras. (Translated by Benjamin Jowett). Available at: http://www.gutenberg.org/1/5/9/1591/

$37 \quad$ Andenæs, Alminnelig strafferett, 2nd rev. ed.(Universitetsforlaget 1974b) at p. 75. 
give unconditional imprisonment for the committed action. Around the peak in the middle of the curves in figure 4 are the very many participants whose total PS-values are a result of different mixtures of the two orientations.

\section{A common normative basis: Sanctions according to the principle of proportionality}

Individually, lay people differ in their orientations to what is most important when choosing sanctions for committed crimes. But in spite of the disagreements among respondents in both samples about which punishment they would inflict on the perpetrator, lay people in both samples - unequal in size and established by totally different procedures give surprisingly equal results (table 1, figure 1) on an aggregate level, and figure 2 and 3 indicate that there is a fairly good fit between actual level of punishment and medians for PS-values for the punishments that the respondents would inflict.

How is this - individual level disagreement and aggregate level concordance - possible?

Although participants in the two studies underestimate the courts' use of imprisonment, figure 2 indicates that a common standard probably might be at work when professional judges mete out punishments and people choose sanctions for the same crimes. It is as if both judges' and lay people's selections of sanctions are guided by an 'invisible hand' - which I will suggest is a common fundamental normative standard.

However, I find it unreasonable to suppose that lay peoples' choices of sanctions are based on knowledge of penal law. Since normative questions are involved in any process where actions are evaluated and sanctions considered, I take it that the study participants have acted normatively, guided by simple moral principles, when they read and evaluated the cases and chose sanctions they would inflict. I further suggest that these processes are intuitive, generally not based on conscious protracted deliberations. While watching some of the focus groups through a one-way screen when the participants answered the questionnaire, I was struck by how rapidly they made up their minds about sanctions. Completing the questionnaire during half an hour did not leave much time for pondering, but the focus group participants did not seem to be frustrated, and they did not complain or ask for more time. The focus group participants had three possibilities to choose sanctions for the perpetrator in one of the six cases they discussed. Analysis of these data shows an astonishing degree of stability in choices of sanctions, in spite of one hours' discussion of punishments. ${ }^{38}$ That indicates that the ticked off sanctions are

38 After discussions participants who had chosen sanctions in the first questionnaire that give exceptionally low or high total PS-values tended, however, to choose other sanctions after the discussions. The PS-values of these sanctions brought their total PS-value closer to the median. This shows that participants who experienced during group discussions that they were real "deviants" in their group 'normalised' their choices of sanctions. 
fairly robust choices, even if they were done rapidly. Participants in the post survey could spend three months to answer the same questionnaire, and they could consult anyone or use any other kind of help, but they gave practically the same answers as the focus group participants' intuitively based answers. Time at disposal beyond half an hour to answer the questionnaire apparently does not influence the result.

The questionnaire studies leave no doubt that lay people find it legitimate to sanction the perpetrators for the actions described in the questionnaire, as they could freely choose sanctions they intuitively found most just or appropriate. An important aspect of justice is to treat equal cases equally and unequal cases unequally. For reasons of justice, actions deserving unequal disapproval should be sanctioned unequally, and I think that any reasonable person would find it unjust to sanction an action deserving little disapproval harder than an action deserving more reprimand. I think that we all feel intuitively that it must be the other way around. This is what the normative principle of proportionality between blameworthiness of an action and the sanction for it is about. This principle is of vital importance in penal sentencing, and I take it that it is a reasonable candidate as the 'invisible hand' producing the observed concordances in figure 2 about sanctions for crimes.

Robinson and Darley suggest that people share a common moral basis, which is relevant for evaluation of a perpetrator's blameworthiness and for determination of punishments. ${ }^{39}$ I agree with this and with their later suggestion that there might be a strong and widely accepted tendency among people to apply relatively simple moral principles that serious wrongs should be punished, and that the punishment should be proportional to the perpetrator's blameworthiness. ${ }^{40}$

The reason why the actual level of punishment corresponds fairly well with medians of PS-values in four of six cases in both data sets might be that both laypeople and judges determine penal sanctions in accordance with the principle of proportionality. There is no doubt that the principle of proportionality is a fundamental principle in Norwegian penal law. This is a fundamental principle for meting out punishments whether one subscribes to the philosophy of retribution or to more utility-oriented philosophies of punishments. ${ }^{41}$ Commitment to justice is always vital when determining punishment, Andenæs claims, and 'punishment cannot be so harsh that it is not fairly proportional to the crime' even if the goal is of a preventive kind. ${ }^{42}$ Because of this he denoted his theory of punishment a 'modified utility theory' in which the principle of proportionality will curtail punishments motivated by utility reasons. In a study of arguments sustaining

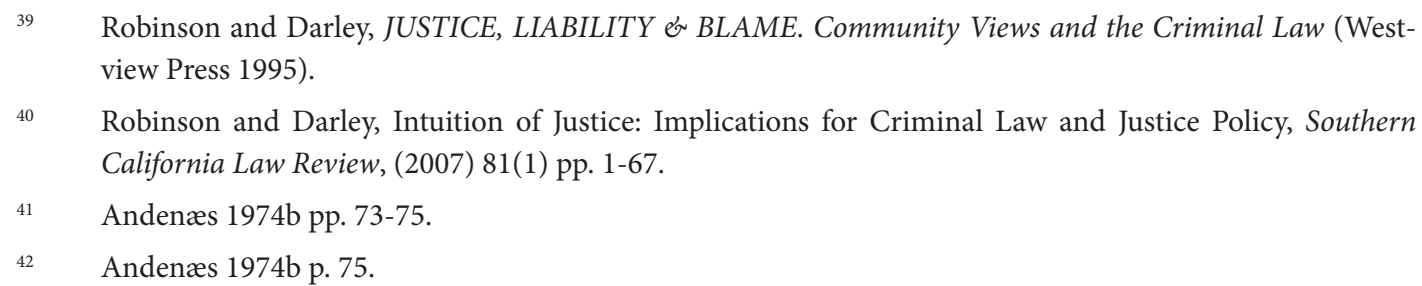


amendments in statutory penal law and reasons given by the Norwegian Supreme Court for changing lower court sentences, it was found that the principle of proportionality was referred to very frequently. ${ }^{43}$ In more general policy discussions about punishment in Norway, politicians also frequently refer to shared intuitional standards for just punishments. A very clear and explicit example can be found in the first ever White Paper to Stortinget about criminal justice policy. ${ }^{44}$ The White Paper discussed different general theories legitimising punishment and concluded that the principle of proportionality 'generally accepted as a social reality' in the Norwegian society - was both a safer reason for punishment than utility theories, and also a principle of justice which limit the use of punishment:

\footnotetext{
Justice does not only limit the use of punishment. A claim for justice is also a reason in itself for punishing and for determination of punishment. The notion that certain norm violations should be countered with a proportional sanction is in itself a social reality and is generally accepted. It is a social reality that the claim for justice is a safer reason for punishment than theories founded on punishment as a means to obtain other goals. Even if theories of the last type should not be valid, there is good reason to believe that punishment as a sanction against undesirable actions will be maintained for reasons of justice. 45
}

Eskeland considers the principle of proportionality as one of the fundamental cultural values of the penal justice system. ${ }^{46}$ It both frames the political freedom to make statutory penal law and the courts' discretion to use their power to punish. And he argues that the principle of proportionality should limit the weight of preventive purposes in decision processes about punishments. ${ }^{47}$ Likewise Aall argues that the principle of proportionality is a basic principle also in penal procedure. ${ }^{48} \mathrm{I}$ think that this indicates that both politicians and lawyers consider that this argument is both just, generally well understood and accepted among people. Shortly, it is a basic principle with high degree of legitimacy. But Eskeland correctly observes that wishes to protect society might grow so strong that the principle of proportionality is sidelined - like what happened when punishments for drug related crimes were steadily increased between 1964 and $1984 .{ }^{49}$ That brought our use of punishment beyond what is a rational approach to drug problems according

\footnotetext{
43 Strandbakken and Matningsdal, Straffenivå og straffeteorier i norsk strafferett anno 2001, Jussens venner (2004) 1 pp. 1 - 17.

44 St. meld. nr. 104 (1977-78) Om kriminalpolitikken (Justis og Politidepartementet).

45 St. meld. nr. 104 (1977-78) pp. 30-31 (my translation).

$46 \quad$ Eskeland, Strafferett (Cappelen Akademisk forlag 2000) p. 52.

$47 \quad$ Eskeland 2000 p. 54.

48 Aall, Prosessuelle garantier og forholdsmessighet i straffeprosessen, Jussens Venner (2013) pp. 227-258.

$49 \quad$ Eskeland 2000 p. 55.
} 
to Andenæs, even if he thought that the threat of punishment had contributed to more negative attitudes toward drugs in the population. ${ }^{50}$

I will briefly add some other reasons why I think it is reasonable to suggest that general commitment to the principle of proportionality among lay people might produce an outcome like shown in figure $2 .{ }^{51}$ Firstly, the principle of proportionality seems to be generally applied in social life. If you buy lots of something, you accept to pay more than if you only buy a little. Most people find it reasonable to pay more for high quality than for low quality, and we give presents as marks of regard for favours from someone, paying attention to value or symbolic balance between present and favours. If A frequently invites B for dinner, B expects to be invited to A, etc. Applying the principle of proportionality to determine sanctions for crimes will only be a specific application of a widely applied social norm. Secondly, the principle of proportionality is known and has been applied to cases of violence in the Norwegian society since the early Middle Ages when laws stipulated detailed guidelines for wound fines ${ }^{52}$ to be paid, according to circumstances, how the victim was attacked, and how badly injured he was:

\footnotetext{
If a man wounds another, he shall pay the wound fine to the one whom he injured: an ora if [the weapon] touched [him]; an ora if it cut the flesh; an ora if the edge strikes the leg; an ora for every [bit of] bone that has to be removed if the silver rings in the scales [i.e. if the money is ready for payment]; an ora for every place that is burned in dressing [a wound], unless there is proud flesh [to remove]; an ora for every time the lips twitch [in pain]; an ora for every tear in the clothing an ora if the man was sitting alone [in private when he was attacked]; an ora if he was just rising from bed; an ora for every cut that has to be made [in dressing the wound], if the cut bleeds; half a mark for a wound in the chest or the abdomen; half a mark if the wound goes in to the marrow; an ora if the weapon comes out [on the other side]. And [let men] appraise the scar and [other] external blemishes, defects, or disabilities. Now, the one who caused the wound shall pay for the leech and the remedies and provide the injured man with victuals, a month's food of both kinds [i.e. butter and meal]. If a man cuts [a bit of] flesh off another and it drops to the ground, he shall pay a compensation of six oras, and six oras if rough scars form on the head. The wounded man shall have witnesses, if the other man denies that joints of the size claimed were [actually] broken. Wounds on the breast shall all be inspected [and valued], and wounds on the back [shall be] twice as dear as those on the breast. If a man is present at a fight and does not try to separate the men or give aid to either side, he shall pay twelve oras to the king as a baug for torpid indifference. 53
}

The quoted section doubles the fines to be paid for wounds on the back. That communicates the moral judgment that attacks from behind are much worse than frontal attacks

$50 \quad$ Andenæs, Straffen som problem. 2nd rev. ed. (Exil Forlag 1996) pp. 79-83.

$51 \quad$ More details are available in Olaussen (2013) pp. $156-175$.

52 Wound fine was only one of several fines to be paid in such cases.

$53 \quad$ The Earliest Norwegian Laws Being the Gulathing Law and the Frostathing Law. Translated from the Old Norwegian by Laurence M. Larson (Columbia University Press MCMXXXV [1935]) section 185. 
are, i.e. the quoted law was not only concerned with injuries caused by actions, but also with wrongs, the moral quality of actions which depends on the actors mind, on his or her spirit and reason for which the action was done. ${ }^{54}$ Many parallels between moral blameworthiness and guilt in criminal cases were discussed by the Norwegian philosopher Knut Erik Tranøy, ${ }^{55}$ who referred to Joel Fienberg's monumental four-volume The Moral Limits of the Criminal Law, and asserted that penal law presumably has taken over and imbedded distinctions in general moral thinking.

Thirdly, Robinson, Kurzban and Jones referred to eighteen studies documented by Robinson and Darley ${ }^{56}$ and reviewed further studies to sustain their conclusion that a 'wide variety of empirical studies indicate that people broadly share intuitions that serious wrongdoing should be punished and also share intuitions about the relative blameworthiness of different transgressions ${ }^{37}$ Lerner emphasises that we have a tendency to react angrily if confronted with situations we interpret as unjust and emotionally arousing. ${ }^{58}$ We tend to respond with sanctions that we feel are suitable to re-establish a just situation. The actions described in the questionnaire might very well have evoked emotional arousing bringing about incentives for sanctions able to re-establish justice.

Fourthly, a precondition for the principle of proportionality to produce results like those in figure 2 is that people tend to rank the actions described in the questionnaire equally according to their blameworthiness. I cannot prove that my respondents would agree on rank between the six cases, but several American studies have documented that there is an amazing degree of agreement across different social groups about the rank or$\operatorname{der}$ (but not degree) of seriousness of as many as 141 actions used in some of the studies. ${ }^{59}$ I don't find any reason to believe that there would be more disagreement about rankings based on actions' blameworthiness in Norway, which is a culturally more homogenous society than the American. Fifthly, there are also studies that have documented a relationship between crime seriousness as evaluated by laypeople and their suggested punishments for the crimes. Warr, Meyer and Ericksson found that seriousness of crime was

Duff, Answering for Crime. Responsibility and Liability in the Criminal Law (Hart Publishing 2007) at p. 119. Tranøy, Det åpne sinn. Moral og etikk mot et nytt årtusen (Universitetsforlaget, Oslo 2001) at pp. 88-94. Robinson and Darley (1995).

Robinson, Kurzban and Jones, The Origins of Shared Intuitions of Justice, Vanderbilt Law Review (2007) 60(6) pp. 1633-1688, p. 1636.

Lerner, The Justice Motive: Where Social Psychologists Found It, How they Lost It, and Why They May Not Find It Again, Personality and Social Psychology Review (2003) 7(4) pp. 388-399.

Sellin and Wolfgang, The Measurement of Delinquency (John Wiley 1964), Velez-Diaz and Megargee, An investigation of differences in value judgments between youthful offenders and non-offenders in Puerto Rico, The Journal of Criminal Law, Criminology and Police Science (1970) 61(4) pp. 549-553, Figlio, The seriousness of offences: An evaluation by offenders and non-offenders, The Journal of Criminal law \& Criminology (1975) 66(2) pp. 189-200, and Pontell, Granite, Keenan and Geis, Seriousness of Crimes: A Survey of the Nation's Chiefs of Police, Journal of Criminal Justice (1985) 13(1) pp. 1-13. 
the key (probably the only) criterion for respondents' selection of punishment. ${ }^{60}$ Rossi, Berk and Campbell, who conducted an extensive continental US interview study to evaluate the federal guidelines for punishments, found a moderate individual level correlation (.59) between the guidelines' ranking of crimes according to seriousness and that of the respondents. ${ }^{61}$ On the aggregate level they found a very high correlation (.87) between medians for punishments suggested by study respondents and the guideline punishments based on seriousness of actions. Jacoby and Cullen, who explicitly tested the importance of the principle of proportionality in a national sample of adults, found that people disagreed very much about which punishment they would inflict (like they did in the Norwegian study). ${ }^{62}$ In spite of that, the analysis led them to conclude that: 'Consensus exists on punishing crimes according to relative degrees of harm, but little consensus exists on absolute amounts of punishment.' ${ }^{63}$ This is precisely what I suggest as an apt interpretation of Norwegian data presented above.

So far all arguments have been connected to punishment, to an approach I denoted retribution-oriented. But a problem-oriented approach to sanctioning was prevailing among a significant number of focus group participants. Which principles did they follow when they selected sanctions for the perpetrators?

Paying regard to the offender's future or hoping that the sanction will serve to rehabilitate the offender does not entail that the principle of proportionality is irrelevant; on the contrary. If the assumed causes of his wrong action or his criminal way of life are not so deeply entrenched, the dose of a correcting sanction or treatment does not need to be as big as when causes are deeply entrenched. For example, because the heroin smuggler had been a drug addict for about ten years according to what he said in the mock film, 76 percent of focus groups participants would sentence him to treatment while the comparable percentage was 37 for the kiosk robber who said that he only used drugs in weekends.$^{64}$ For these perpetrators it was also argued that imprisonment would be detrimental because of easily available drugs in prisons. Further, only 19 percent would sentence the man who committed assault to treatment and 13 percent the rapist; obviously because these perpetrators did not seem have any kind of problem for which there is a treatment. The treatment term which focus group members would give, tend to be long: 81 percent

60 Warr, Meier and Ericksson, Norms, Theories of Punishment, and Publicly Preferred Penalties, The Sociological Quarterly (1983) 24(1) pp. 75-91.

${ }_{61}$ Rossi, Berk and Campbell, Just Punishments: Guideline Sentences and Normative Consensus. Journal of Quantitative Criminology, (1997) 13(4), pp. 267-290.

62 Jacoby and Cullen, The Structure of Punishment Norms: Allying the Rossi-Berk Model, The Journal of Criminal Law \& Criminology (1999) 89(1) pp. 245-312.

$63 \quad$ Jacoby and Cullen 1999 p. 296.

${ }_{64}$ All percentages here refer to sanctions focus group participants ticked off in the questionnaire after discussion. 
was one year or more for the four cases discussed, and longest for the heroin smuggler who had the most serious drug problems.

Community punishment is another sanction claimed by some of the focus group participants to be a more effective rehabilitating sanction - or at least less detrimental - than imprisonment. This sanction too seems to be meted out according to the degree of the offender's problem. However, relatively few ticked off this sanction, so the pattern is less clear than for treatment. Economic compensation to the victim was to some degree ticked off both by participants who were retribution-oriented and those who were problem-oriented, and it was ticked off more frequently than treatment and community punishment. Arguments for giving economic compensation were not only to compensate the victim for the harm, but also to punish the perpetrator; to remind him every month for years about his offence. Some argued that this would be a more just punishment than imprisonment for harms that reduce the victim's quality of life a very long period, perhaps the victim's whole lifetime. Not surprisingly, the size of the economic compensation ticked off varies from case to case. Thirty three percent of focus group participants would sentence the offender in the robbery case to pay compensation to the kiosk assistant who was threatened with a knife but not physically injured. Nearly half of these compensations were less than $50.000 \mathrm{NOK}$. About 70 percent of respondents would give economic compensation in the rape and assault cases. However, while 57 percent of compensations were $100.000 \mathrm{NOK}$ or more in the rape case, the comparable percentage was five percent for assault. In this case 68 percent of economic compensations were $50.000-100.000$ NOK. No doubt, focus group participants distributed payment of compensation according to the principle of proportionality, a principle applied in Norwegian (penal and tort) law already in the early Middle Ages.

An interview study conducted by Christie among 98 homeless alcoholics and persons charged for property crimes in pretrial custody confirms that this group of Norwegians found the proportionality principle to be just. ${ }^{65}$ They were interviewed about their expectations and attitudes to the punishment they believed that the court would give them. Christie found that both respondent groups believed that the principle of retribution was dominating in the courts, and that general deterrence was barely mentioned by his respondents. Their arguments for the sanction they would have given themselves clustered around justice and proportionality: This and that offence would lead to this and that punishment. What was considered as most just was that society should retaliate proportionately to the offence.

The arguments mentioned above summarise why I think that the principle of proportionality is of crucial importance for lay Norwegians' selection of sanctions as responses to the actions described in the questionnaire. Independent of each informant's tendency

65 Christie, Varetekstsfangers forventninger og innstillinger til straff, Nordisk Tidsskrift for Kriminalvidenskab, (1955) pp. 210-232. 
to punish (harshly), I suggest that all of them applied the principle of proportionality (unconsciously) when they chose sanctions for the perpetrators in the six cases. It was applied because it leaves a feeling of having acted in a just way.

There is a way to test whether the Norwegian participants apply equal standards when they suggest punishments for the perpetrators: Consider the four groups in table 2 as subgroups with different tendencies to punish harshly (weak, fairly weak, fairly strong and strong). Then calculate the median of PS-values for each crime for every subgroup and use the 24 calculated medians to draw separate curves for each subgroup. This has been done for both data sets and the results for focus group data are displayed in figure 5 .

Figure 5: Medians of punishments which focus group respondents themselves would impose for each of the six cases depending on the respondent's tendency to punish harshly. (Weighted data.)

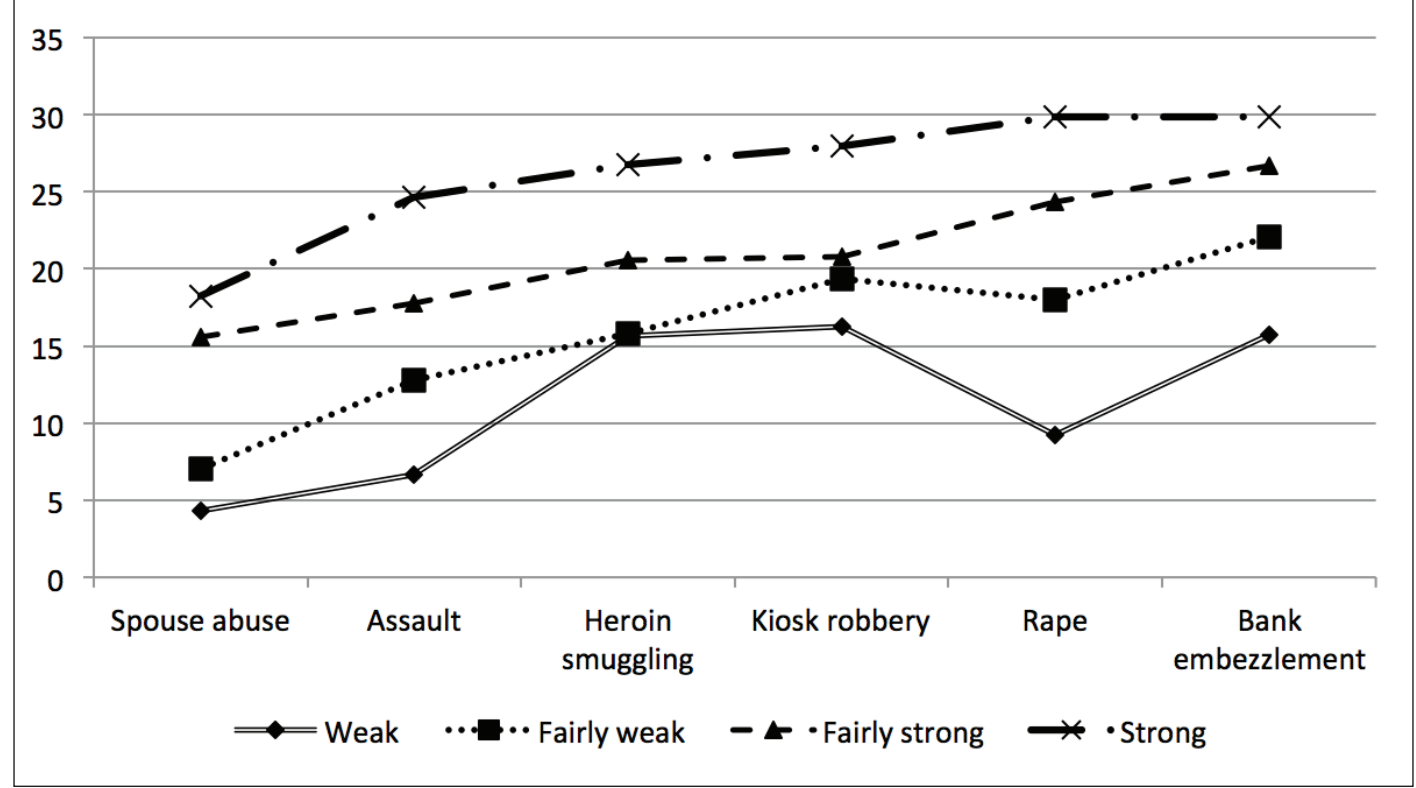

If the hypothesis that participants apply a common standard in all four subgroup is correct, the curves connecting the medians should run parallel to each other. These curves in figure 5 are sufficiently parallel to conclude that they sustain the hypothesis, except the curve for focus group participants with a weak tendency to punish (harshly), the lowest curve. ${ }^{66}$ The main reason why this curve is not parallel with the other three curves is connected to two cases, heroin smuggling and kiosk robbery. Respondents who have a weak tendency (are least inclined) to give harsh sanctions, would give far harsher sanctions

66 The corresponding diagram for participants in the post survey, see Olaussen (2013), figure 7.3 at p. 182 does not show a deviant pattern for heroin smuggling and kiosk robbery. 
than expected for heroin smuggling and kiosk robbery. Why these deviations? Common for the two cases is that the perpetrators were using drugs and their actions were planned. The attempted heroin smuggling was committed by a person who had been addicted to heroin many years, and the young man who committed kiosk robbery used cocaine and amphetamine now and then (during weekends). I know from discussions in the focus groups that some participants thought that use of drugs was the reason why the man committed the kiosk robbery. The argued that he owed lots of money for drugs he had bought from unspecified "friends", who demanded him to pay. Since drug use and drug related crimes often are considered as very serious and blameworthy actions in the Norwegian society, this was possibly also the view among relatively many focus group participants who did not tend to punish the perpetrator in the other cases very harshly. An additional reason for harsh sanctions for the two crimes might be that the actions were planned, committed with premeditation (malice aforethought), which is a morally aggravating circumstance untypical for the rest of the cases.

Figure 2 shows that the actual level of punishment for bank embezzlement and heroin smuggling were significantly higher than medians for PS-values that study participants would give. The two crimes stand out as deviations in an ordered pattern of correspondence between the actual level of punishment and sanctions that the respondents in both studies would inflict. Don't these deviations falsify my simple, general model of compliance between lay people's thinking about crime and punishment and basic principles in penal law? I don't think so. The deviations that bank embezzlement and heroin smuggling represent in figure 2 might very well be a result of a professional sentencing ideology which deviates from moral intuitions about proportionality applied by lay people. The most likely reason why the actual level of punishment is significantly higher than the median for PS-values for heroin smuggling and bank embezzlement is faith in deterrence theory. It is an important theory also in Norwegian penal philosophy ${ }^{67}$ and it is a 'standard wisdom' among prosecutors and judges when they give reasons for sentences for certain crimes. General deterrence has often been a decisive argument for harsher punishments for drug crimes, including heroin smuggling, ${ }^{68}$ and the very harsh punishments for drug crimes in Norway is to a large extent based on belief in deterrence effects of imprisonment. In addition, heroin smuggling is an act outside the core of crimes (often called mala in se, wrongs an sich), constituted of attacks on people or their belongings. Some might not feel intuitively that it is wrong to smuggle heroin and commit bank embezzlement in the same sense as it is wrong to attack directly another person, which was done in the other four cases. This difference might have contributed to reduce harshness

See Andenæs, Punishment and Deterrence (University of Ann Arbor Press 1974a) and his General Prevention revisited: research and policy implications, Journal of Criminal Law and Criminology (1975) 66 (3) pp. 338-365. 
of punishments that lay people would inflict for heroin smuggling and for bank embezzlement.

Faith in deterrence effects among politician, prosecutors and judges might also contribute to more severe penal sanctions for different kinds of white-collar crime, like the case about bank embezzlement, because such crimes normally are committed by rational and planning actors, who presumably will be deterred by harsh sanctions. In addition, such sanctions might be considered necessary to sustain trust in vital social institutions like banks. Deterrence arguments are not equally convincing for cases like spousal abuse, rape, and assault, where aroused emotions seem to play an important role. Weaker relevance of deterrence arguments in these cases probably is a reason why there is high degree of concordance between judges and lay people. Maybe lay people's intuitive choice of sanctions is only marginally influenced by thoughts typical for rational penal theory? Having reviewed lots of studies, Robinson states that

\footnotetext{
'[1]aypersons do not intuitively apply principles of deterrence, incapacitation, and rehabilitation when they assess criminal liability and punishment. To the contrary, the studies suggest that lay assessments of criminal liability and punishment conflict with, rather than track, coercive crime control strategies'.69
}

In a more restricted sense, this is true also for focus group participants who discussed punishments. Very few of them used deterrence or incapacitation arguments. But Robinson's claim is not generally true, especially not for rehabilitation, which is an argument in accordance with Max Weber's assertion that rational purposive thinking is deeply engraved in modern minds. This is probably why this way of thinking often is considered as legitimate, also when punishments are considered.

\section{$7 \quad$ Concluding remarks}

The population studies undertaken the autumn 2009 indicate strongly that amendments in penal law passed by Stortinget in 2009-2010 leading to significantly harsher punishments for violent crimes, including rape, was not an outcome of claims among ordinary citizens for harder punishments. The only data in the study that appear to sustain the enactments are answers given in the telephone survey, but these answers are given by people who don't know the actual level of punishment, and underestimate it. The legitimacy of imprisonment is weaker among ordinary citizens than among Norwegian politicians because many think that this punishment is not conducive as a means to reduce recidivism. It might rather give it a boost.

69 Robinson, Why Does the Criminal Law Care What the Layperson Thinks is Just? Coercive Versus Normative Crime Control, Virginia Law Review (2000) 86(8) pp. 1839-1869, p. 1858. 
Before the amendments, there seems to have been a fairly good concordance between the actual level of punishment practiced by courts and the median of punishments that lay people would in inflict for specific criminal actions. The probable reason for this is that both professional judges and lay people agree that punishments should be determined according to the principle of proportionality. Lack of concordance between lay people's suggested punishment and the actual penal level of punishment for heroin smuggling and bank embezzlement probably indicates that the actual level of punishment in these cases is inflated by professional and political faith in general deterrence.

The disagreements among lay people about punishment for specific actions are not incompatible with our knowledge that professional and lay judges agree in 95 percent of sentences in real criminal cases, even though I don't think that this unanimity is due to professional judges' pressure or persuasive powers over lay judges. At the closure of ordinary court hearings of cases, the prosecutor and defence attorney frequently indicate the punishment they think is appropriate and just. However, this kind of advice was not given to respondents in the population studies. If we had included information about actual penal level in the final questionnaire answered after the group discussions, we would have known more about how this might influence lay people's considerations of just punishments.

Because the respondents did not have information about actual penal level, they were spared a question relevant for any judge in a real court case: Is it just to give this person a punishment which differs from what is normal in cases of the same kind? I strongly believe that also lay judges intuitively feel that justice demands the application of the norm of 'equal sanctions for equal misdeeds', and that very few intuitively feel that it is just to deviate from this norm that agrees nicely with the principle of proportionality. 